\title{
Effects of pH and titratable acidity on the growth and development of Monilinia laxa (Aderh. \& Ruhl.) in vitro and in vivo.
}

\author{
Vitus Ikechukwu Obi • Juan Jose Barriuso • \\ Yolanda Gogorcena
}

Accepted: 25 December 2017

(C) Koninklijke Nederlandse Planteziektenkundige Vereniging 2018

\begin{abstract}
This investigation examines the effects of $\mathrm{pH}$ and titratable acidity on the growth and developments of a strain of Monilinia laxa (Aderhold \& Ruhland) at seven different $\mathrm{pH}$ levels in Potato Dextrose Agar media and on peach fruit from formation to commercial maturity. The fungi growth was obtained by daily measurement of mycelia on the $\mathrm{pH}$ amended Potato Dextrose Agar. The sporulation performance was determined after 30 days of culture incubation. Fruits were inoculated with M. laxa, from fruit set to maturity, on weekly basis for brown rot susceptibility. The pathogen development, in vitro, was affected, by the $\mathrm{pH}(2.4-11.52)$ amended nutrient media. M. laxa exhibited variation in its growth and sporulation capacities on the seven $\mathrm{pH}$ amended PDA, preferring relatively moderate acidic conditions for optimum performance. In the in vitro analysis, there was mycelia growth at $\mathrm{pH} 2.40$ to 8.84 , while $\mathrm{pH} 11.52$ did not support any mycelia growth. There was a continuous and stable increase in weight of fruit as it developed whereas the fruit size increased, then decreased and finally increased as the fruit develops. The acidity
\end{abstract}

Electronic supplementary material The online version of this article (https://doi.org/10.1007/s10658-017-1413-4) contains supplementary material, which is available to authorized users.

V. I. Obi $(\bowtie) \cdot Y$. Gogorcena

Estación Experimental de Aula Dei-CSIC, Avda. de Montañana 1005, 50059 Zaragoza, Spain

e-mail: vitemma@live.com

\section{J. J. Barriuso}

Instituto Agroalimentario de Aragón IA2, CITA-Universidad de Zaragoza, Zaragoza, Spain dynamics exhibited a non-sinusoidal waveform through the growth and development of the fruit. In all these characteristic variations, M. laxa did not develop infection or shown any brown rot incidence in the fruit until the period of commercial maturity.

Keywords Alkaline $\cdot$ Monilia $\cdot$ Physicochemical .

Prunus persica . Tolerance

$\begin{array}{ll}\text { Abbreviations } \\ \text { BRI } & \text { Brown rot incidence } \\ \text { DAF } & \text { Days after floration } \\ \text { DAS } & \text { Days after fruit set } \\ \text { EpHV } & \text { Expected pH values } \\ \text { FS } & \text { Fruit size } \\ \text { FW } & \text { Fruit weight } \\ \text { JDs } & \text { Julian days } \\ \text { PDA } & \text { Potato dextrose agar } \\ \text { PP } & \text { Polypropylene } \\ \text { RPM } & \text { Revolutions per minute } \\ \text { RpHV } & \text { Real pH values } \\ \text { TA } & \text { Titratable acid. }\end{array}$

\section{Introduction}

Brown rot in peaches (Prunus persica (L.) Batsch) is a disease primarily incited by Monilinia species which includes M. laxa, M. fructigena, M. fructicola, and $M$. polystroma (Gell et al. 2007; Jansch et al. 2012). The degree of susceptibility to infection by Monilinia spp. is 
variable throughout fruit development. Susceptibility is high during the early stages of fruit development, decreases during the green fruit stage and increases again during the ripening period (Gradziel 1994). Stages of peach development can generally be considered to occur in four phases which includes, fruit set, rapid cell division, cell expansion and ripening/maturation (Moing et al. 1998; Tutu and Ciornea 2011; Guidarelli et al. 2014).

In a pathogen-host interaction the growth and development of microorganism is influenced by different physicochemical conditions such as temperature and water activity (Pascual et al. 1997; Xu et al. 2001; Moral et al. 2012), light, aeration and pressure (Maharshi and Thaker 2012), $\mathrm{pH}$ and titratable acidity (Pascual et al. 1997; Dirlewanger et al. 1999; Holb 2004; RomeroArenas et al. 2012). During this process the physicochemical conditions influence the microbial activity determining either the growth and reproduction or the inhibition of activity and the inactivation of the pathogen (Dirlewanger et al. 1999; Tutu and Ciornea 2011).

The $\mathrm{pH}$ and titratable acidity (TA) are interrelated concepts of organic acids (Tyl and Sadler 2017) controlling physicochemical factors that act in an additive and interactive mode to inhibit metabolic pathway (Dirlewanger et al. 1999). These two physicochemical components, though complementary in nature, are statutorily different. TA refers to the total concentration of free protons and undissociated acids in a fruit juice that can react with a strong base and be neutralized, hence it is any amount of base needed to neutralize such acidity and bring its $\mathrm{pH}$ to a neutral ( $\mathrm{pH} 7$ ), or slightly alkaline ( $\mathrm{pH}$ 8.1) value, and $\mathrm{pH}$ represents the free hydrogen ion activity in the fruit juice (Lobit et al. 2002) or a means of expressing such $\mathrm{H}^{+}$ions concentration in a substrate (Tutu and Ciornea 2011). In peach fruit acidity is an important genetic quality (Dirlewanger et al. 1999) which influences both perception of sourness and sweetness found in varying proportions depending on the cultivar and the ripening stage (Lobit et al. 2002).

The behavior of microorganisms-host interaction shows variation in their growth and sporulation on different levels (Maharshi and Thaker 2012). Most microorganisms, especially non fungi, grow best around neutrality ( $\mathrm{pH} 7)$, while fungi in general prefer slightly acidic conditions for their growth (Alexopoulos 1952; Yamanaka 2003; Agrios 2011; Maharshi and Thaker 2012). Some fungi species, however, favour neutral to slightly alkaline conditions (Maharshi and Thaker 2012). Monilinia spp. can acidify the host tissue in peaches and nectarines from $\mathrm{pH} 4.50$ and 4.45 , to pH 3.75 and 3.90, respectively (De Cal et al. 2013). For M. laxa, information related with the effect of $\mathrm{pH}$ on growth and development in-vitro and in-vivo is hardly available. Monilinia laxa can infect flowers, resulting in blossom blight, as well as both healthy and wounded fruit, resulting in brown rot (Rungjindamai et al. 2014); a disease able to produce millions of spores on a single fruit that can spread quickly within and between orchards, locations, and hosts (Fazekas et al. 2014).

The general objective of this experiment was to determine the modulating effect of $\mathrm{pH}$ and titarable acidity (TA) to pathogenic activities of M. laxa. This included (a) determining the effect of $\mathrm{pH}$ on the mycelia growth, sporulation and development of M. laxa on solid PDA, and (b) to determine the effect of $\mathrm{pH}$ and TA evolution on the brown rot incidence (BRI) depending on the growth and development of peach fruit.

\section{Materials and methods}

Culture $\mathrm{pH}$ media preparation, inoculation and incubation

The cultivation medium, potato dextrose agar (PDA), was prepared in line with the manufacturer's instruction following which $7.8 \mathrm{~g}$ was measured into seven Erlenmeyer flasks $(500 \mathrm{~mL})$ and $200 \mathrm{~mL}$ sterile water added to the different flasks and contents slightly heated in a microwave oven for proper dissolution of mixture. They were sterilized at $121{ }^{\circ} \mathrm{C}$ for $15 \mathrm{~min}$ and, in a laminar flow chamber (aseptic conditions), known quantities of $\mathrm{H}_{2} \mathrm{SO}_{4}$ and $\mathrm{KOH}$ chemicals, as previously determined by titration, were added with a pipetman into the flasks (pH 5.30) marked with the expected $\mathrm{pH}$ values (EpHV) at a warm $\left(45^{\circ} \mathrm{C}-60^{\circ} \mathrm{C}\right)$ temperature. The solution was agitated with a magnetic stirrer at $110 \mathrm{rpm}$ for about $30 \mathrm{~s}$ for homogeneity. Known quantity of $20 \mathrm{~mL}$ was separately and aseptically decanted into $50 \mathrm{~mL}$ transparent polypropylene (PP) jars and a $\mathrm{pH}$ stripe indicator cut and dipped into the jars to observe the associated $\mathrm{pH}$ readings. The molten PDA was later measured with the $\mathrm{pH}$ meter to obtain the real $\mathrm{pH}$ value (RpHV) before pouring out into Petri dishes of $90 \mathrm{~mm}$ diameter at $20 \mathrm{~mL} /$ plate for inoculation with M. laxa. The desired $\mathrm{pH}$ was adjusted with $1 \mathrm{M}$ Hydrogen sulphate $\left(\mathrm{H}_{2} \mathrm{SO}_{4}\right)$ and $5 \mathrm{M}$ Potassium hydroxide $(\mathrm{KOH})$ for acidic, neutral or alkaline values using the $\mathrm{pH}$ meter. Known quantities 
of $\mathrm{H}_{2} \mathrm{SO}_{4}$ or $\mathrm{KOH}$ were, aseptically, added to the sterilized PDA (in $500 \mathrm{~mL}$ Erlenmeyer flasks at a warm $\left(45^{\circ} \mathrm{C}-60{ }^{\circ} \mathrm{C}\right)$ temperature.

The $\mathrm{pH}$ amended PDA were poured out at $20 \mathrm{~mL} /$ Petri dishes of $90 \mathrm{~mm}$ diameter (five Petri dishes/treatment). Active growing (7 days old) $M$. laxa mycelia $(6.5 \mathrm{~mm})$ from a PDA culture was centrally plated in the Petri dish containing the real $\mathrm{pH}$ values (RpHV) and incubated at $23{ }^{\circ} \mathrm{C}$. And later the mycelia growth and extent of sporulation were determined.

Measurements of mycelia growth rate and sporulation density

Measurements of mycelia growth were taken daily using a digital Venier meter (Mitutoyo CD-15 DCX, Tokyo Japan) at a cross section. This was done until a Petri dish was fully covered with the mycelia extension. Rate of extension and influence of $\mathrm{pH}$ on pathogen activity were determined from the mycelia growth. There were five replications for each treatment.

After the data collection on mycelial growth, the culture was subsequently evaluated for sporulation activity at the 30th day of incubation. Distilled water $(5 \mathrm{~mL})$ was added to each of the Petri dishes containing $25 \mu \mathrm{L}$ Tween ${ }^{\circledR} 80$ and the mycelia colony rasped with a sterile laboratory metal spatula. The rasped colony together with the Petri dishes was placed on a mechanical shaker at $175 \mathrm{rpm}$ for $30 \mathrm{~min}$. Each treatment was filtered through a 4-fold of cheese cloth into premarked test tubes. From this suspension, $25 \mu \mathrm{L}$ was pippeted onto a hemacytometer (Neubauer Cell Counting Chamber) and examined under a microscope. Two different spore loads ( 40 counts/load) were made in each replication of the seven treatments.

Plant material, fruit size and weight determination

Two peaches (Prunus persica (L.) Batsch) were the source of plant materials. The Plant materials were 'Babygold 9' and 'Crown Princess' from the collection of the Aula Dei-CSIC, Zaragoza. There were three trees per cultivar. Number two (middle tree) was marked and labeled after fruit setting for use in the evaluation. The marked tree was not thinned to enable enough fruits for sample harvest. Numbers 1 and 3 trees were however given the normal orchard treatments (e.g. fruit thinning). Fruits selected for analysis were all of similar maturity and size at each developmental stage. Inoculation with
M. laxa was completed on 'Babygold 9' and not on 'Crown Princess' after observing that there was no infection at the early stage of inoculation. And the aim was to preserve enough samples for other essential analysis due to fewer available fruits on the 'Crown Princess'.

The range of complete floration and fruit settings in the two cultivars (Table 1) occurred in the early to midseason of spring between 10/03/2014 and 11/04/2014; and the range of harvest date occurred in the early to mid-season of summer. 'Babygold 9' reached $100 \%$ floration and fruit setting on the 14/03/2014 (72 JDs) and the 11/04/2014 (100 JDs) respectively and harvested on the 21/08/2014 (232 JDs). 'Crown Princess' reached $100 \%$ floration and fruit setting on the 10/03/ 2014 (68 JDs) and fruit setting on the 11/04/2014 (100 JDs) and harvested on the 18/06/2014 (168 JDs).

Five fruits per cultivar were used for evaluations on a weekly basis. Fruits of visually uniform size were harvested for each period. Fruit size ( $\mathrm{mm}$ ) was determined by measuring the two diagonal sections with a digimatic venier caliper (Mitutoyo CD-15 DCX, Tokyo Japan). The fruit weight $(\mathrm{g})$ was determined on a precision weighing machine.

\section{Development of $\mathrm{pH}$ and titratable acidity}

TA and $\mathrm{pH}$ were determined as explained in previous studies (Cantín et al. 2009; Abidi et al. 2015). In brief, three fruits were used per cultivar for this purpose. On a weekly basis after setting, fruits were harvested, cleaned with tap water, peeled and cut into thin slices. Five grams was weighed out into an automatic titrator tube and mashed dry with a polytron machine (Ika T-18 Ultra Turrax Digital High Speed Homogenizer, Germany) and later $45 \mathrm{~mL}$ of distilled water measured into the titrator tube. The $\mathrm{pH}$ automatic valuator machine was first calibrated using a buffer (for $\mathrm{pH} 4$ and $\mathrm{pH} 8$ ). This is after cleaning and flushing the electrodes with distilled water then filled with electrolyte $(\mathrm{KCl})$ for compensation of any possible loss due to evaporation. The known quantity of the solution $(50 \mathrm{~g})$ in the automatic valuator was used to determine the $\mathrm{pH}$ with TA values accordingly. This was repeated every week until the cultivar reached commercial maturity date (Larena et al. 2005).

Evaluation for susceptibility to Monilinia

Five fruits per cultivar were used for this determination. Fruits were disinfected according to Obi et al. (2017). 
Table 1 Complete floration, fruit settings and harvest in two peach cultivars (gestation period)

\begin{tabular}{llll}
\hline Activity & 'Babygold 9' & 'Crown Princess' & BBCH-scale \\
\hline Floration (100\%) & $14 / 03 / 2014$ (72 JDs) & $10 / 03 / 2014$ (68 JDs) & 65 \\
Fruit setting (100\%) & $11 / 04 / 2014$ (100 JDs) & $11 / 04 / 2014$ (100 JDs) & 73 \\
Harvesting date & $22 / 08 / 2014$ (233 JDs) & $12 / 06 / 2014$ (162 JDs) & 87 \\
\hline
\end{tabular}

Using a Pipetman P100, fruits were inoculated with the isolate of M. laxa in the method of Obi et al. (2017). In brief each fruit, unwounded, was inoculated with $25 \mu \mathrm{L}$ spore load of the $25 \times 10^{3} \mathrm{cfu} \mathrm{mL}^{-1}$ conidia suspension. Inoculated samples were incubated at $23{ }^{\circ} \mathrm{C}$ and 40 $60 \% \mathrm{RH}$ and duly observed for brown rot incidence for seven days.

\section{Statistical analysis}

The size, weight, $\mathrm{pH}$ and TA of fruit, including their standard errors were analyzed using the SPSS-23 statistical software (Statistical Product and Service Solutions Inc., Chicago USA). An earlier normality test was realized on parameters with the Kolmogorov-Smirnov test $(P \geq 0.05)$, enabling the presentation of frequency of histograms. The same statistical software was used for mean standard errors (SE) and Pearson's correlations. An ANOVA test was used to compare differences between means and a post hoc test of the Duncan (DMRT) was used to measure for separation $(P \leq 0.05)$ between pairs of means.

\section{Result}

Mycelial growth

Mycelial growth or extent of colonization was evaluated at seven levels of $\mathrm{pH}$. There was mycelia growth in all the $\mathrm{pH}$ levels except at $\mathrm{pH} 11.52$. The highest mycelia growth was at $\mathrm{pH} 6.40(80.61 \mathrm{~mm})$ at the rate of $8.96 \mathrm{~mm} /$ day. The lowest mycelial growth was at $\mathrm{pH} 2.40(11.60 \mathrm{~mm})$ at the rate of $1.29 \mathrm{~mm} /$ day (Fig. 1). Mean values varied according to the extent of colonization.

\section{Sporulation capacity}

Sporulation capacity was determined using the $M$. laxa colonies of the seven different levels of $\mathrm{pH}$ after 30 days of incubation. Sporulation was found to be highest at $\mathrm{pH} 5.30$ with mean conidia concentration of over $1 \times$ $10^{5} \mathrm{cfu} \mathrm{mL}^{-1}$ and lowest at $\mathrm{pH} 8.84$ with mean conidia of less than $5 \times 10^{4} \mathrm{cfu} \mathrm{mL}^{-1}$ (Fig. 2). There was no sporulation of M. laxa at $\mathrm{pH} 2.40,3.01$ and 11.52. There were, however, significant differences $(\mathrm{P} \leq 0.05$, Duncan's test) in the sporulation capacity among pH 4.21, 5.30, 6.40 and 8.84.

Development of $\mathrm{pH}$ and TA in 'Babygold 9' and 'Crown Princess'

The evolution of $\mathrm{pH}$ and TA in fruits of 'Babygold 9'and 'Crown Princess' cultivars were non-sinusoidal waveforms. This waveform is best demonstrated in the 'Babygold 9' (Figs. 3 and 5) which has a longer period of gestation. In this particular cultivar the $\mathrm{pH}$ peak (highest) was at 208 JDs (77 BBCH scale) which corresponds to 136 and 108 days of complete floration and fruit setting respectively. The lowest dip was at 215 JDs (78 $\mathrm{BBCH}$ scale) which was equivalent to 143 and 115 days after floration (DAF) and days after setting (DAS) respectively. From this position the $\mathrm{pH}$ increased along with the remaining growth and commercial maturity of the fruit.

In all this non-sinusoidal waveform dynamics of $\mathrm{pH}$ in 'Babygold 9', the pattern in TA evolution was always in the contrary (Fig. 3), hence the lowest dip was at 208 JDs (77 BBCH scale) which corresponds to 136 and 108 DAF and DAS respectively. The highest peak was at 215 JDs (78 BBCH scale) which was equivalent to 143 and $115 \mathrm{DAF}$ and DAS respectively. From this position the TA decreased along with the remaining growth of the fruit.

Growth in fruit size and weight

The growth in fruit size (FS) and weight (FW) is presented in Fig. 4. FS was at steady increase for well over 194 JDs (75 BBCH scale). This pattern slightly changed at $201 \mathrm{JDs}$ (76 $\mathrm{BBCH}$ scale) where there was a slight 
Fig. 1 Mycelia growth rate of Monilinia laxa ( $\mathrm{mm})$, in vitro, on the 7 different $\mathrm{pH}$. M. laxa performed best at $\mathrm{pH} 6.4$ and lowest at $\mathrm{pH} 2.4$. No mycelium at $\mathrm{pH}$ 11.52. Each treatment was replicated five times and experiment repeated twice

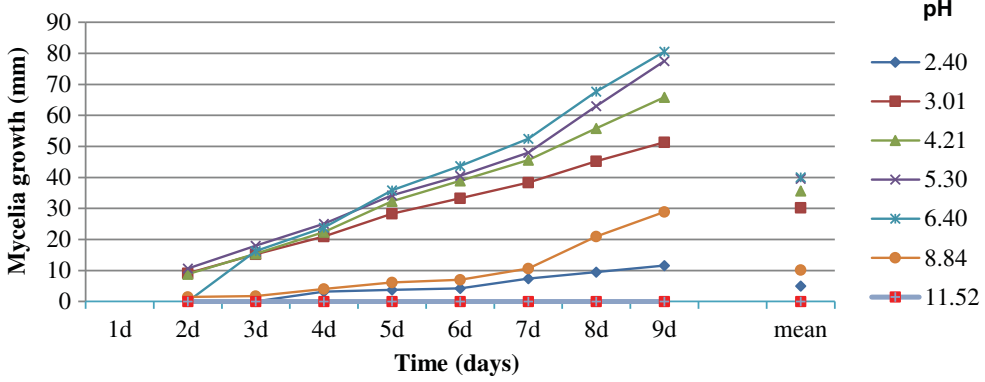

brown rot until when the fruit was inoculated at the 232 JDs (79 BBCH scale) of commercial maturity.

$\mathrm{BBCH}$ scale) and then a gentle smooth increase in size until the fruits' period of commercial maturity and subsequent harvest on the 232 JDs (79 BBCH scale).

In the same vein, $\mathrm{FW}$ was at a steady increase for over a period of $201 \mathrm{JDs}$ (76 BBCH scale). This pattern changed at the 208 JDs (77 BBCH scale) when a noticeable rapid increase was observed. This increase appeared to have continued until the fruits' period of commercial maturity and subsequent harvest on the 232 JDs (79 BBCH scale).

\section{Effect of $\mathrm{pH}$ and TA on brown rot incidence}

Figure 5 represents the effect of $\mathrm{pH}$ and TA on brown rot incidence along with the growth and development of the fruit. After the highest increase in $\mathrm{pH} 4.39 \pm 0.10$ at 208 JDs (77 BBCH scale) and the lowest dip in $\mathrm{pH} 3.63 \pm$ 0.10 at $215 \mathrm{JDs}$ ( $78 \mathrm{BBCH}$ scale), the $\mathrm{pH}$ re-initiated and continued to increase until fruit maturity. The reverse was the case with the TA which started to decrease until maturity ( $\mathrm{pH}$ and TA linked with broken lines at 208 JDS (77 BBCH scale). Hence at the full commercial maturity, the fruit was associated with $\mathrm{pH} 4.19 \pm 0.10$ and TA 0.41 \pm 0.01 (Mg $\left.100 \mathrm{~g}^{-1} \mathrm{FW}\right)$. From the beginning of fruit inoculation (145 JDs) (65 BBCH scale) with M. laxa to $222 \mathrm{JDs}$ (78 $\mathrm{BBCH}$ scale) there was no incidence of

\section{Discussion}

In general, according to the obtained results in this investigation, there was an ample influence of $\mathrm{pH}$ and titratable acidity (TA) in the solid PDA and the peach cultivars inhibiting the growth of the M. laxa. According to Tutu and Ciornea (2011), the pathogen-host interaction involves the process of nutrition, which leads to either growth/reproduction or the inhibition of activity and the inactivation of the pathogen as a result of available acidity. In the $\mathrm{pH}$-amended PDA, there was no effective pathogen growth/development under a high acidic condition. Similarly, M. laxa developed no infection in the fruit until commercial maturity at $\mathrm{pH} 4.19 \pm$ 0.10 . This is relatively a moderate state of non-acidity in the fruit. Previously, peach fruits with a non-acid character have been characterized at maturity by a $\mathrm{pH}$ higher than 4.0 (Dirlewanger et al. 1999).

Mycelia growth (colonization) and sporulation are the most accurate variables to effectively compute the degree of disease development (Douds 1994; Gigot et al. 2009; Miles et al. 2009; Burnett et al. 2010; Obi et al. 2017). Consequently, determining the influence
Fig. 2 Sporulation capacity of Monilinia laxa on 7 different $\mathrm{pH}$ at 30 days of incubation. Different mean letters indicate significant differences ( $P \leq 0.05$, Duncan's test) among $\mathrm{pH}$. $M$. laxa sporulated highest at $\mathrm{pH} 5.30$. No sporulation at $\mathrm{pH} 2.40,3.01$ and 11.2. Each treatment was replicated five times and experiment repeated twice

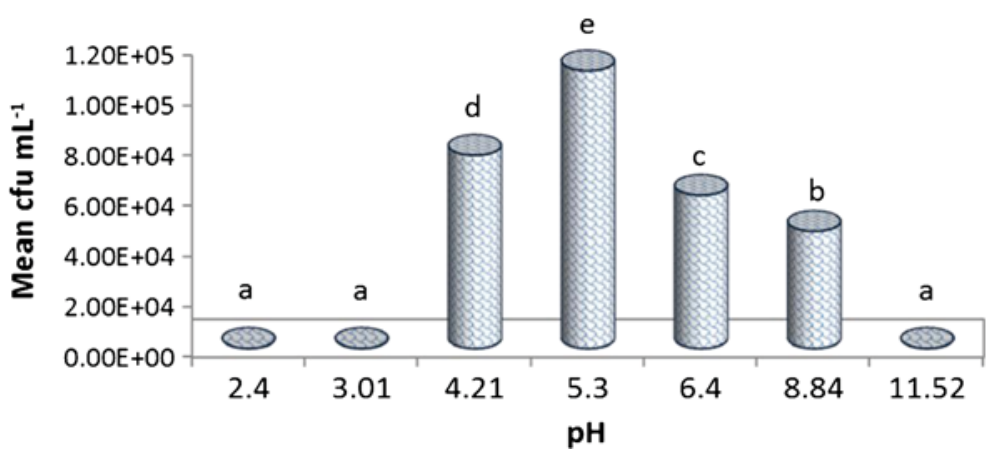




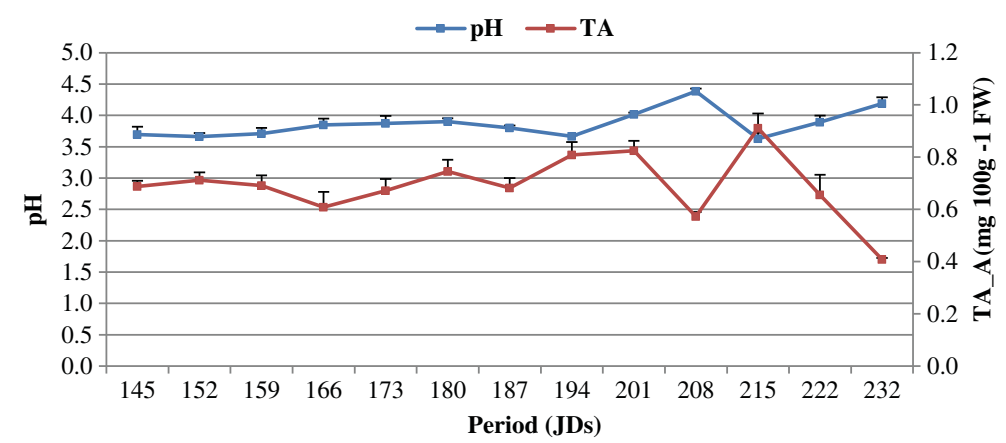

Fig. 3 The evolution of $\mathrm{pH}$ and TA plus SE in 'Babygold 9' fruit. Fruits were harvested once a week and each treatment replicated 3 times. There was significant difference $(P \leq .0 .05$, Duncan test) in $\mathrm{pH}$ of fruits among weeks of harvest. However, no significant difference in the $\mathrm{pH}$ of fruit among 145, 152 and 194 JDs; and

of $\mathrm{pH}$ and TA on the development of M. laxa, at both in vitro and in vivo levels is an avenue to understanding the epidemiology of brown rot and subsequent development of disease management strategies to effectively combat the problem (Tian and Bertolini 1999; Hong et al. 2000).

Sporulation itself is a function of colonization (Douds 1994). Colonization concerns dimension (size or area) occupied by infection while sporulation deals with population (conidia or spores) involved in an occupied or diseased area. This implies that sporulation is the subsequent effect of colonization due to infection (Xu et al. 2001). However, we have found according to our results that a high rate of colonization did not equate to high rate of sporulation. Hence the extent of lesion or colonization does not always equate to the degree of sporulation in a host-pathogen interaction but depends on available level of acidity as shown by this experiment. among 166, 173,180, 187, and 222 JDs. There was significant difference $(\mathrm{P} \leq .0 .05$, Duncan test) in TA of fruits among weeks of fruit harvest. However, no significant difference in TA of fruits among 145, 152, 159 and 187 JDs; and among 166 and 222 JDs. (See supplementary Table 1 for details)

For example, in our assay the mycelia growth or extent of colonization at $\mathrm{pH} 6.40$ and 5.30 were $80.61 \mathrm{~mm}$ and $77.50 \mathrm{~mm}$ producing mean conidia concentrations of 60,800 and 110,800 spores $\mathrm{mL}^{-1}$ respectively (Figs. 3 and 4). Though the extent of colonization was higher at $\mathrm{pH} 6.40$ than at $\mathrm{pH} 5.30$, sporulation was found to be higher at $\mathrm{pH} 5.30$ than at $\mathrm{pH} 6.40$ with about $45.13 \%$. This appears to suggest that sporulation of M. laxa increases as the $\mathrm{pH}$ increases, reaches its maximum in the acidic region, and then descends as the $\mathrm{pH}$ approaches neutral and then alkaline.

We are of the view, therefore, that M. laxa could sporulate at a wide range of $\mathrm{pH}$ between 3.5 and 9.5 with the optimum between $\mathrm{pH} 4.5$ and 5.5. This is similar to, and in agreement with, the results of Agarwal and Sarboy (1978) that acidic $\mathrm{pH}$ favours fungi growth with best performance within the range of $\mathrm{pH}$ 3.5-6.5. Pascual et al. (1997) observed a pH 4-6 range for optimum

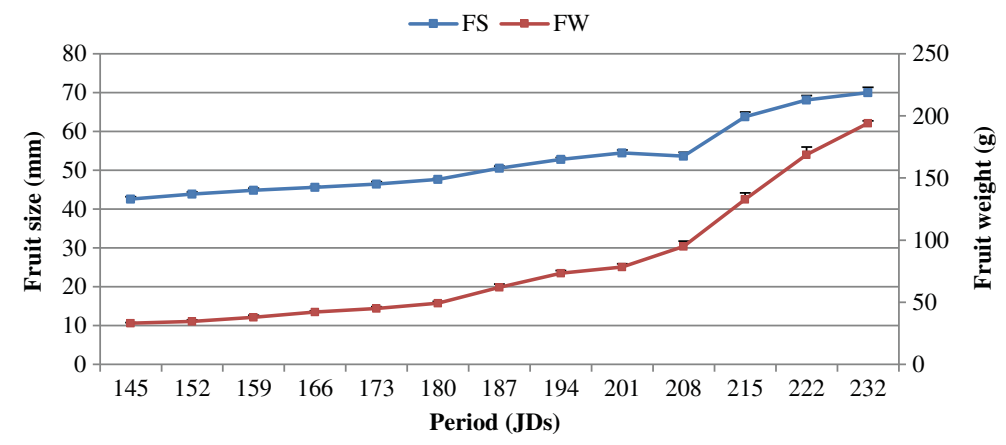

Fig. 4 The evolution of size (mm) and weight (g) plus SE in 'Babygold 9' from setting to fruit maturity. Fruits were harvested at weekly basis and each treatment replicated five times. There was significant difference $(\mathrm{P} \leq 0.05$, Duncan test $)$ in fruit size between weeks. However, no significant differences found in the size of fruits harvested at 194, 201 and 208 JDs; 222 and 232 JDs. There was significant difference $(\mathrm{P} \leq 0.05$, Duncan test) in fruit weight between weeks. No significant difference found in weight of fruit harvested at 145 and 152 JDs; 194 and 201 JDs. (See supplementary Table 1 for details) 
Fig. 5 The effect of $\mathrm{pH}$ and titratable acidity (TA) plus standard error (SE) on the susceptibility to brown rot incidence (BRI) of 'Babygold 9' from immature to fruit maturity. Five fruits were inoculated and three fruits evaluated for acidity at weekly basis. The broken line between $\mathrm{pH}$ and TA at $208 \mathrm{JDs}$ indicates a clear and unique nonsinusoidal characteristics of acidity in the evolution of peach fruit

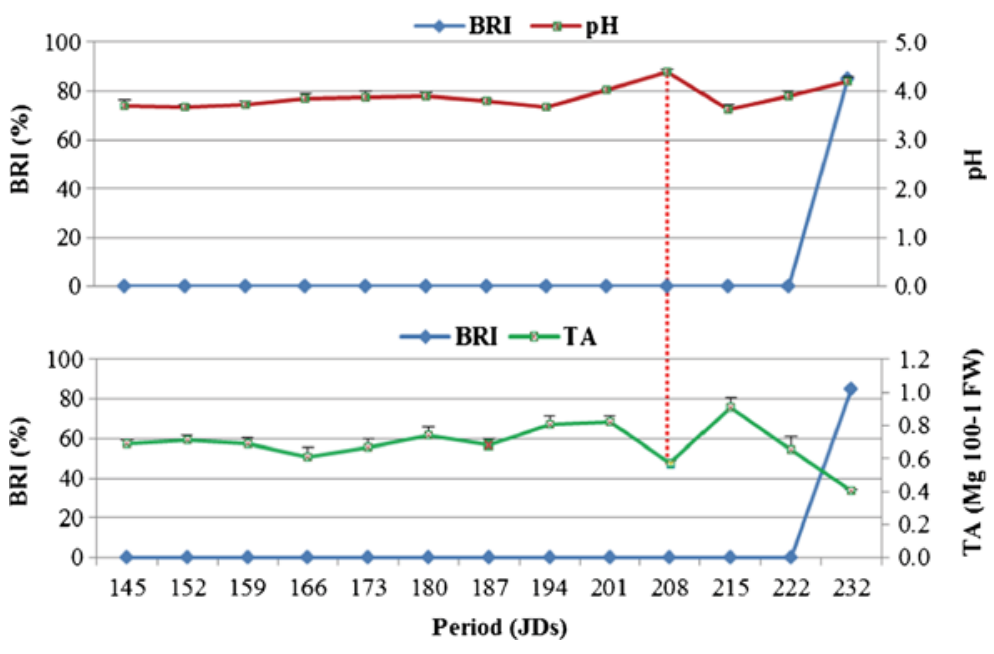

reduction in organic accumulation, which results in fruit with lower acidity and higher $\mathrm{pH}$ as was determined in our work at 208 JDs (77 BBCH scale). This tends to support Moing et al. (1998) that such physicochemical activity occurs well before ripening. Stages of peach development are considered to occur in four phases which includes: fruit set, rapid cell division, cell expansion, and ripening/maturation (Tutu and Ciornea 2011).

Hence the most resistant period to pathogen infection in peach fruit is during the stages covering pit hardening to pre-harvest (Keske et al. 2011). It could, therefore, be inferred that immature peaches are very resistant to brown rot because of high levels of acidic $\mathrm{pH}$ found in the epidermal cells. This high level of $\mathrm{pH}$ could have inhibited brown rot incidence at the immature stages in'Babygold 9'due to acidification activities. Gluconic acid has been reported as the main organic acid associated with the enhancement of peach acidification in host-pathogen interactions (De Cal et al. 2013). $M$. laxa colonized the 'Babygold 9' at the commercial stage of maturity (232 JDs) (79 BBCH scale) when the acidic $\mathrm{pH}$ had reduced, probably aided by local acidification of the host tissue (De Cal et al. 2013).

It is noteworthy, however, that in the inoculation of uninjured 'Babygold 9' with the normal conidia from immature to mature fruit state, the effects of inoculating with mycelia on both injured and uninjured immature fruits were also determined simultaneously. The observations indicate that: at $145 \mathrm{JDs}(65 \mathrm{BBCH}$ scale) $(\mathrm{pH} 3.69 \pm 0.13)$ there was no BRI when fruit was inoculated with $25 \mu \mathrm{L}$ of $25 \times 10^{3} \mathrm{cfu} \mathrm{mL}^{-1}$ spores on artificial injury. There was also no BRI in fruits without artificial injury inoculated with $25 \mu \mathrm{L}$ of $25 \times 10^{3} \mathrm{cfu}$ expansion phase. In peach fruit there is usually a 
$\mathrm{mL}^{-1}$ spores. There was, however, BRI in the immature fruit with artificial injury inoculated with a $6.5 \mathrm{~mm}$ mycelia PDA. In addition, at 222 JDs ( $78 \mathrm{BBCH}$ scale) (pH $3.89 \pm 0.11$ ), within the fruit colour break, there was no BRI in fruits with intact skin (no artificial injury) when inoculated with $25 \mu \mathrm{L}$ of $25 \times 10^{3} \mathrm{cfu} \mathrm{mL}^{-1}$ spores. To the contrary, artificially injured fruits showed BRI when inoculated with $25 \mu \mathrm{L}$ of $25 \times 10^{3} \mathrm{cfu} \mathrm{mL}^{-1}$ spores.

The significance of these observations is that the degree of susceptibility to infection by Monilinia spp. is variable throughout fruit development (Gradziel 1994; Guidarelli et al. 2014). Our findings support this assertion because in our experiment at the early stage of growth and development, immature fruit could not exhibit brown rot symptoms when inoculated with conidia, neither through injury site nor on intact epidermis, but could only develop infection when inoculated with mycelium when injured. Furthermore, at colour-break 222 JDs (78 BBCH scale), peach fruit at $\mathrm{pH} 3.89 \pm 0.11$ could develop infection with conidia inoculation only through an injury and on the fruit epidermis. Hence skin injury could be responsible for the incident of brown rot on immature peach fruits observed in orchards (Northover and Biggs 1990; Holb 2004).

Further, FW at maturity $(194.04 \pm 1.99)$ was significantly different $(P \leq 0.05$, Duncan test) from the rest of the FW at development. Also the $\mathrm{pH}(4.19 \pm 0.10)$ and TA $(0.41 \pm 0.01)$ values at maturity were all significantly different from those of the development values (Supplementary Table 1). Pearson's correlation shows inverse correlations between $\mathrm{pH}$ and all the pathological activities on peach cultivars at harvest. Harvest date (HD) significantly correlated with fruit size (FS) $(r=$ $0.912, P<0.01)$; fruit weight (FW) $(r=0.889, \mathrm{P}<$ $0.01)$; and $\mathrm{pH}(r=0.440, \mathrm{P}<0.01)$. Also FS significantly correlated with FW $(r=0.980, \mathrm{P}<0.01)$. There was a significant correlation between $\mathrm{pH}$ and FW $(r=0.356$, $P<0.05)$. As expected, however, $\mathrm{pH}$ inversely correlated significantly with TA $(r=-0.604, p<0.01)$.

Finally while there was a continuous and stable increase in weight of fruit as it develops, the reverse was the case for fruit size. There was fluctuation in the size as the fruit developed. Fruit size increased, later decreased and finally increased as the fruit developed. The dynamics in $\mathrm{pH}$ and TA values also occurred when there were clear changes in fruit size and weight evolution. In addition, the $\mathrm{pH} 4.19 \pm 0.1$ at which $M$. laxa could infect the peach in this work relatively correlate with the range of $\mathrm{pH}$ (3.59.5) in the solid PDA considered to support sporulation in vivo. Hence brown rot infection and expression in peach fruit is dependent on the influence of $\mathrm{pH}$ and TA and in extension upon the stage of the fruit growth (Emery et al. 2000; Holb 2004; Gell et al. 2009). This study encompasses the necessity to know the development of fruit maturity in new and old varieties in relation to potential Monilinia infection in immature fruits.

This study has shown that M. laxa exhibited variation in its growth and sporulation capacities on the seven $\mathrm{pH}$ amended PDA levels, preferring relatively moderate acidic conditions for optimum performance. We found, in the in vitro analysis, that there was mycelia growth at $\mathrm{pH} 2.40$ to 8.84 , while $\mathrm{pH} 11.52$ did not support mycelia growth. The $\mathrm{pH} 5.30$ supported the highest sporulation while $\mathrm{pH} 6.40$ encouraged the highest colonization extent or mycelia growth. This supports the findings of Holb (2004) that the most favorable initial hydrogenion concentration for mycelial growth occurs between $\mathrm{pH} 3.5$ and 5.5. We found that there was a continuous and stable increase in weight of fruit as it develops, the reverse being the case in fruit size. The fruit size increased, decreased and finally increased as the fruit develops. The $\mathrm{pH}$ dynamics exhibited non-sinusoidal waveforms through the growth and development of the fruit. In all these physicochemical variations, M. laxa could not develop infection or show any brown rot incidence in the fruit until the period of commercial maturity. On the basis of this study it can be concluded that $\mathrm{pH}$ and titratable acidity have great impacts on the growth activity of M. laxa in a host-pathogen association both in solid PDA substrate and in peach fruit growth and development and could be important determining elements to be given attention in peach breeding programs.

Acknowledgements We thank Dr. J. Usall of the (IRTA Lleida) for providing the original inoculum of the M. laxa; to Dr. M.A. Moreno (EEAD-CSIC) for providing plant material; and to R. Giménez (EEAD-CSIC) for technical assistance. The Research Center and Food Technology of Aragón (CITA) allowed us the use of its plant protection facilities.

Funding This work was financed by the MINECO and the Government of Aragón with projects AGL2014-52063R A44; co-financed with FEDER and ESF, respectively.

\section{Compliance with ethical Standard}

Conflict of interest The authors have declared that there is no conflict of interest exists. 
Research involving Human Participants and/or Animals This article /manuscript does not contain any studies with human and /or animal subjects performed by any of the authors.

Informed consent This article is as a result of a general study in the evaluation of peach germplasm for tolerance to brown rot by Monilinia laxa at the Aula Dei-CSIC peach collection, Zaragoza. I, Vitus Ikechukwu Obi, testify on behalf of all co-authors (Yolanda Gogorcena and Juan Jose Barriuso) that our article.

Title: "Effects of $\mathrm{pH}$ and titratable acidity on the growth and development of Monilinia laxa (Aderh. \& Ruhl.) in vitro and in vivo",

a) has not been published in whole or in part elsewhere;

b) is not currently being considered for publication in another journal; c) and that all authors have been personally and actively involved in substantive work leading to the manuscript, and will hold ourselves jointly and individually responsible for its content.

\section{References}

Abidi, W., Cantín, C. M., Jiménez, S., Giménez, R., Moreno, M. A., \& Gogorcena, Y. (2015). Influence of antioxidant compounds, total sugars and genetic background on the chilling injury susceptibility of a non-melting peach [Prunus persica (L.) Batsch] progeny. Journal of the Science of Food and Agriculture, 95, 351-358. https://doi.org/10.1002/jsfa.6727.

Agarwal, D. K., \& Sarboy, A. K. (1978). Physiological studies on four species of Fursarium pathogenic to soyabean. Indian Phytopathology, 31, 24-31.

Agrios, G. N. (2011). Plant Pathology. USA: Academic Press, Inc.. Alexopoulos, C. J. (1952). Introductory Mycology. New York: WIE, John Wiley \& Sons, Inc..

Amiri, A., Holb, I. J., \& Schnabel, G. (2009). A new selective medium for the recovery and enumeration of Monilinia fructicola, M. fructigena, and M. laxa from stone fruits. Phytopathology, 99, 1199-1208.

Burnett, A. L., Lalancette, N., \& McFarland, K. A. (2010). Effect of QoI fungicides on colonization and sporulation of Monilinia fructicola on peach fruit and blossom blight cankers. Plant Disease, 94, 1000-1008.

Cantín, C. M., Gogorcena, Y., \& Moreno, M. Á. (2009). Evaluation of the antioxidant capacity, phenolic compounds, and vitamin c content of different peach and nectarine [Prunus persica (L.) Batsch] breeding progenies. Journal of Agriculture and Food Chemistry, 57, 4586-4592.

Emery, K. M., Michailides, T. J., \& Scherm, H. (2000). Incidence of latent infection of immature peach fruit by Monilinia fructicola and relationship to brown rot in Georgia. Plant Disease, 84, 853-857.

De Cal, A., Sandín-España, P., Martinez, F., Egüen, B., ChienMing, C., Lee, M. H., Melgarejo, P., \& Prusky, D. (2013). Role of gluconic acid and $\mathrm{pH}$ modulation in virulence of Monilinia fructicola on peach fruit. Postharvest Biology and Technology, 86, 418-423.

Dirlewanger, E., Moing, A., Rothan, C., Svanella, L., Pronier, V., Guye, A., Plomion, C., \& Monet, R. (1999). Mapping QTLs controlling fruit quality in peach Prunus persica (L.) Batsch. Theory and Applied Genetics, 98, 18-31.
Douds, D. D. (1994). Relationship between hyphal and arbuscular colonization and sporulation in a mycorrhiza of Paspalum notatum Flugge. New Phytologist, 126, 233-237. https://doi. org/10.1111/j.1469-8137.1994.tb03941.x.

Fazekas, M., Madar, A., Sipiczki, M., Miklós, I., \& Holb, I. (2014). Genetic diversity in Monilinia laxa populations in stone fruit species in Hungary. World Journal of Microbiology and Biotechnology, 30, 1879-1892. https://doi.org/10.1007 /s11274-014-1613-4.

Gell, I., Cubero, J., \& Melgarejo, P. (2007). Two different PCR approaches for the universal diagnosis of Brown rot and identification of Monilinia spp. in stone fruit trees. Journal of Applied Microbiology, 103, 2629-2637.

Gell, I., De Cal, A., Toress, R., Usall, J., \& Melgarejo, P. (2009). Conidial density of Monilinia spp. on peach fruit surfaces in relation to the incidences of latent infections and brown rot. European Journal of Plant Pathology, 123, 415-424.

Gigot, J. A., Gundersen, B., \& Inglis, D. A. (2009). Colonization and Sporulation of Phytophthora infestanson volunteer potatoes under Western Washington conditions. American Journal of Potato Research, 86, 1-14. https://doi.org/10.1007 /s12230-008-9054-y.

Gradziel, J. (1994). Changes in susceptibility to Brown rot with ripening in three clingstone peach genotypes. American Society of Horticural. Science, 119, 101-105.

Guidarelli, M., Zubini, P., Bertolini, P., Nanni, V., \& Barald, E. (2014). Gene expression analysis of peach fruit at different growth stages and with different susceptibility to Monilinia laxa. European Journal of Plant Pathology, 140, 503-513. https://doi.org/10.1007/s10658-014-0484-8.

Gupta, V. K., Gaur, R. K., \& Misra, A. K. (2010). Physiological characterization of Fusarium spp. isolates, causing wilt of guava in India. Journal of Plant Protection Research, 50, $452-456$

Holb, I. J. (2004). Effect of acidity on growth rate and stroma formation of Monilia fructigena and M. polystroma isolates. International Journal of Horticultural Science, 10, 63-67.

Hong, C. X., Michailides, T. J., \& Holtz, B. A. (2000). Mycoflora of stone fruit mummies in California orchards. Plant Disease, $84,417-422$

Jansch, M., Frey, J. E., Hilber-Bodmer, M., Broggini, G. A. L., Weger, J., Schnabel, G., \& Patocchi, A. (2012). SSR marker analysis of Monilinia fructicola from Swiss apricots suggests introduction of the pathogen from neighboring countries and the United States. Plant Pathology, 61, 247-254.

Keske, C., Amorim, L., \& May-De Mio, L. L. (2011). Peach brown rot incidence related to pathogen infection at different stages of fruit development in an organic peach production system. Crop Protection, 30, 802-806. https://doi. org/10.1016/j.cropro.2011.03.005.

Larena, I., Torres, R., De Cal, A., Liñán, M., Melgarejo, P., Domenichini, P., Bellini, A., Mandrin, J. F., Lichou, J., Ochoa de Eribe, X., \& Usall, J. (2005). Biological control of Postharvest Brown rots (Monilinia spp.) of peaches by field applications of Epicoccum nigrum. Biological Control, 32, 305-310

Lobit, P., Soing, P., Génard, M., \& Habib, R. (2002). Theoretical analysis of relationships between composition, $\mathrm{pH}$, and titratable acidity of peach fruit. Journal of Plant Nutrition, 25, 2775-2792. https://doi.org/10.1081/PLN-120015538. 
Maharshi, A. R., \& Thaker, V. S. (2012). Growth and Development of Plant Pathogenic Fungi in Define Media. European Journal of Experimental Biology, 2, 44-54.

Miles, A. K., Akinsanmi, O. A., Sutherland, P. W., Aitken, E. A. B., \& Drenth, A. (2009). Infection, colonization and sporulation by Pseudocercospora macadamiae on macadamia fruit. Australasian Plant Pathology, 38, 36-43.

Moing, A., Svanella, L., Rolin, D., Gaudllere, M., Gaudillere, J. P., \& Monet, R. (1998). Compositional changes during the fruit development of two peach cultivars differing in juice acidity. Journal of the American Society for Horticultural Science, 123, 770-775.

Moral, J., Jurado-Bello, J., Sánchez, M. I., De-Oliveira, R., \& Trapero, A. (2012). Effect of Temperature, Wetness Duration, and Planting Density on Olive Anthracnose Caused by Colletotrichum spp. Phytopathology, 102, 974-981.

Northover, J., \& Biggs, A. R. (1990). Susceptibility of immature and mature sweet and sour cherries to Monilinia fructicola. Plant Disease, 74, 280-284.

Obi, V. I., Barriuso, J. J., Moreno, M. A., Giménez, R., \& Gogorcena, Y. (2017). Optimizing protocols to evaluate brown rot (Monilinia laxa) susceptibility in peach and nectarine fruits. Australasian Plant Pathology, 46, 183-189. https://doi.org/10.1007/s13313-017-0475-2.

Pascual, S., Rico, J. R., De Cal, A., \& Melgarejo, P. (1997). Ecophysiological factors affecting growth, sporulation and survival of the biocontrol agent Penicillium oxalicum. Mycopathologia, 139, 43-50.

Romero-Arenas, O., Damián-Huato, M. A., Israel Hernández Treviño, I. H., Parraguire-Lezama, J. F. C., Aragón-García,
A., \& Arellano, A. D. (2012). Effect of $\mathrm{pH}$ on growth of the mycelium of Trichoderma viride and Pleurotus ostreatus in solid cultivation mediums. African Journal of Agricultural Research, 7, 4724-4730.

Rungjindamai, N., Jeffries, P., \& Xu, X. (2014). Epidemiology and management of brown rot on stone fruit caused by Monilinia laxa. European Journal of Plant Pathology, 140, 1-17. https://doi.org/10.1007/s10658-014-0452-3.

Tian, S. P., \& Bertolini, P. (1999). Effect of temperature during conidial formation of Monilinia laxa on conidial size, germination and infection of stored nectarines. Journal of Phytopathology, 147, 635-641.

Tutu, E., \& Ciornea, E. (2011). The influence of H+ ions concentration on the dynamics of the activities of certain dehydrogenases of the Krebs cycle in the Monilinia laxa (Aderh. \& Ruhl.) Honey fungus parasitic on plum trees. Biologie Molecular, TOM XII, 2011.

Tyl, C., \& Sadler, G. D. (2017). pH and Titratable Acidity. In S. Nielsen (Ed.), Food Analysis. Food Science Text Series. Cham: Springer. https://doi.org/10.1007/978-3-319-45776-5 22.

Xu, X. M., Guerin, L., \& Robinson, J. D. (2001). Effects of temperature and relative humidity on conidial germination and viability, colonization and sporulation of Monilinia fructigena. Plant Pathology, 50, 561-568. https://doi. org/10.1046/j.1365-3059.2001.00606.x.

Yamanaka, T. (2003). The effect of $\mathrm{pH}$ on the growth of saprotrophic and ectomycorrhizal ammonia fungi in vitro. Mycologia, 95, 584-589. 